\title{
Physiological Responses of Apple and Cherry In Vitro Culture under Different Levels of Drought Stress
}

\author{
Zuzana Kovalikova ${ }^{1,+}$, Petra Jiroutova ${ }^{2, *,+}{ }^{\circ}$, Jakub Toman ${ }^{1}$, Dominika Dobrovolna ${ }^{1}$ and \\ Lenka Drbohlavova ${ }^{2}$ \\ 1 Department of Biology, Faculty of Science, University of Hradec Kralove, Rokitanskeho 62, \\ 50003 Hradec Kralove, Czech Republic; zuzana.kovalikova@uhk.cz (Z.K.); jakub.toman@uhk.cz (J.T.); \\ dominika.dobrovolna@uhk.cz (D.D.) \\ 2 Research and Breeding Institute of Pomology Ltd., Holovousy 129, 50801 Hořice, Czech Republic; \\ lenka.drbohlavova@vsuo.cz \\ * Correspondence: petra.jiroutova@vsuo.cz \\ + These authors contributed equally to this work.
}

Received: 5 October 2020; Accepted: 28 October 2020; Published: 30 October 2020

\begin{abstract}
Drought stress is a serious threat. Therefore, improvements in crop productivity under conditions of limited water availability are vital to keep global food security. Apples and cherries belong to the most produced fruit worldwide. Thus, searching for their tolerant or resistant cultivars is beneficial for crop breeders to produce more resistant plants. We studied five apple ("Malinové holovouské", "Fragrance", "Rubinstep", "Idared", "Car Alexander") and five cherry ("Regina", "Napoleonova", "Kaštánka", "Sunburst", "P-HL-C") cultivars for their adaptation in response to progressive drought stress. The reaction of an in vitro culture to osmotic stress simulated by increasing polyethylene glycol (PEG) concentration in medium was evaluated through the morphological (fresh and dry weight, water content, leaf area), physiological (chlorophyll and carotenoids content), and biochemical (reactive oxygen species and malondialdehyde content) parameters. Drought-like stress negatively affected the water content, leaf areas, and chlorophyll content in both fruit species. Oxidative status and membrane damage of plants under water deficiency conditions occurred to be important indicators of stress tolerance mechanism. Cherries exhibited higher hydrogen peroxide levels compared to apples, whereas their malondialdehyde values were generally lower. The overall results indicated wide tolerance range to water deficit among apple and cherry in vitro culture as well as among cultivars within single plant species.
\end{abstract}

Keywords: drought stress; in vitro culture; apple; cherries; oxidative stress

\section{Introduction}

Drought stress is a major environmental stress negatively affecting growth, development, and the agricultural production of many plants worldwide. Low water availability can be chronic in dry climate regions or unpredictable due to the changes in weather conditions during the period of plant development. It is expected that the areas suffering from water deficiency will be increasing due to global warming. Thus, searching for drought tolerant plant species and cultivars could be beneficial for crop breeders to produce more resistant plants, which could help to maintain the food security under the conditions of the warming world [1]. Selection or breeding of drought resistant fruit species and cultivars in combination with new approaches in effective use of water are considered to improve the crop production and quality under the drought stress conditions [2].

The responses of plants to water deficit depend upon the intensity and duration of the stress conditions as well as plant species/cultivar and its stage of development. In plants, drought 
negatively affects several physiological processes including photosynthesis, respiration, nutrient uptake, and metabolism and causes a complex of physio-biochemical responses [3].

Under water deficit conditions, water uptake by the roots is impaired. This causes the reduction in turgor pressure, resulting in suppression of cell elongation and expression growth [4]. Decreased leaf size is one of the first and most obvious plant responses to water stress. It is caused by both decreased cell development and reduced photosynthesis rate. Reduction in the leaf area associated with decrease in the transpiration surface presents a very important water saving mechanism. Recovery leaf growth is dependent on phases of leaf development and on intensity of stress conditions. Stress occurring at the early phase can be recovered. However, this phenomenon does not occur in later stages of development. Severe drought stress stops both leaf development and the production of new leaves, and accelerates the leaf senescence [5].

Reduction in fresh and dry biomass is another typical physiological response of plants to drought stress that represents unfavorable impact of water stress, especially on crop plants. On the contrary, maintaining fresh and dry weight under water deficit conditions is a desirable character trait of plants, especially of agriculturally important crops because of its impact on yield [6].

Drought stress also affects photosynthetic pigment composition in terms of changing the ratio of chlorophyll $a$ and $b$, and carotenoids [7]. A significant reduction in chlorophyll content under water stress conditions has been reported for many plant species [8-10]. Aside from their essential role in photosynthesis, carotenoids are important non-enzymatic antioxidants playing an essential role in response to various stress conditions [11]. Hence, their level and ratio can increase as a reaction to drought stress [4].

A decrease in leaf size, biomass, photosynthetic pigments, and water availability leads to reduction in the photosynthesis rate, resulting in absorption of more light energy than could be consumed by photosynthetic carbon fixation. This excess energy has the potential to cause an oxidative stress and increase the production of reactive oxygen species (ROS) such as hydrogen peroxide $\left(\mathrm{H}_{2} \mathrm{O}_{2}\right)$ or superoxide radicals $\left(\mathrm{O}^{2-}\right)$. These species react with proteins and lipids, causing damage of cellular structures and the photosynthesis related metabolism [12]. For example, ROS destroy the cellular membrane through lipid peroxidation. During this process, malondialdehyde (MDA) as a product of acid peroxidation is accumulated in the plant. Thus, the determination of the MDA content can be used as a measure of membrane damage-induced oxidative stress during water stress [13].

Polyethylene glycol (PEG) is described as water-soluble, high molecular weight polymers, widely used to induce water stress in higher plants through lowering the water potential of the nutrient solution [14]. PEG is widely used for identification of drought tolerant genotypes under stimulated osmotic stress [14,15]. The major advantage of using in vitro based techniques with the PEG enriched medium is the rapid screening of diverse plant cultures in laboratory conditions. On the other hand, the main limitation of this method is simulation of drought stress conditions by application of osmotic stress, contrary to withhold irrigation methods based on whole plants experiments [16]. Although, the results of Kautz et al. [17] indicate that physiological responses of plants subjected to PEG-induced osmotic stress are similar to physical water deficit, PEG cannot be considered as an unconditional equivalent for natural drought. The objective of this in vitro study was evaluation of selected morphological, physiological, and biochemical characteristics in five different apple ("Malinové holovouské", "Fragrance", "Rubinstep", "Idared", "Car Alexander") and five cherry ("Regina”, “Napoleonova”, “Kaštánka”, “Sunburst", “P-HL-C") cultivars under drought-like stress conditions induced by polyethylene glycol (PEG). We focused on expanding the available information on selected cultivars (Table 1) with respect to their drought tolerance. 
Table 1. Main features of examined apple and cherry cultivars in relation to abiotic stress.

\begin{tabular}{cccc}
\hline Cultivar (Apple) & $\begin{array}{c}\text { Main Feature in Relation to } \\
\text { Abiotic Stress }\end{array}$ & Cultivar (Cherry) & $\begin{array}{c}\text { Main Feature in Relation to } \\
\text { Abiotic Stress }\end{array}$ \\
\hline Malinové holovouské & $\begin{array}{c}\text { Low drought resistance [18]. } \\
\text { Sufficient frost resistance [19]. }\end{array}$ & Regina & $\begin{array}{c}\text { High resistance to } \\
\text { rain-induced splitting [20]. }\end{array}$ \\
\hline Fragrance & $\begin{array}{c}\text { Resistant to winter and } \\
\text { spring frosts [21]. }\end{array}$ & Napoleonova & $\begin{array}{c}\text { Low resistance to } \\
\text { rain-induced splitting [20]. } \\
\text { Tolerant to drought [22]. }\end{array}$ \\
\hline Rubinstep & $\begin{array}{c}\text { Resistant to winter and } \\
\text { spring frosts [23]. }\end{array}$ & Kaštánka & $\begin{array}{c}\text { High resistance to } \\
\text { rain-induced splitting [20]. }\end{array}$ \\
\hline Idared & $\begin{array}{c}\text { Sensitive to winter frosts [24]. } \\
\text { Very resistant to frosts. } \\
\text { High resistance to }\end{array}$ \\
\hline Car Alexander & $\begin{array}{c}\text { Very low drought resistance. } \\
\text { High frost resistance [19]. }\end{array}$ & P-HL-C & Resistant to winter frosts [26]. \\
\hline
\end{tabular}

\section{Materials and Methods}

\subsection{Plant Material and Experimental Conditions}

Selected genotypes of apple (Malus $\times$ domestica) and cherry (Prunus avium) were produced in vitro from donor shoots collected in the Research and Breeding Institute of Pomology Holovousy Ltd., Czech Republic. In vitro explants were cultured on $25 \mathrm{~mL}$ of modified solid (7.0 $\mathrm{g} \mathrm{L}^{-1}$ agar) Murashige and Skoog (MS) medium [27] with 6-aminobenzylpurine (BAP) as the shoot growth stimulant at a concentration of $1.5 \mathrm{mg} \mathrm{L}^{-1}$ in $100 \mathrm{~mL}$ Erlenmeyer flasks capped with aluminum foil. $\mathrm{pH}$ was adjusted to 5.7 before autoclaving at $121^{\circ} \mathrm{C}$ for $15 \mathrm{~min}$. Growth room conditions were: temperature $22 \pm 1{ }^{\circ} \mathrm{C}$, photoperiod $16 \mathrm{~h}$ light $/ 8 \mathrm{~h}$ dark. Viable cultures were transferred to fresh MS medium at 30-day intervals. Osmotic stress was induced by adding polyethylene glycol (PEG-6000) at a concentration of $0,5,10,25$, and $50 \mathrm{~g} \mathrm{~L}^{-1}$ to the basal medium (which is equivalent to $0 \%, 0.5 \%$, $1 \%, 2.5 \%$, and 5\% ( $w / v)$ PEG-6000), labelled as PEG0, PEG5, PEG10, PEG25, and PEG50, respectively. All parameters were measured in plants cultivated at a rate 4 pieces per flask on media (with or without PEG-6000) for 30 days. At least three independent measurements were carried out for each cultivar and each concentration.

\subsection{Determination of Fresh and Dry Weight, Water Content, Leaf Area}

Each explant cultivated under the same conditions was weighed on analytical balance (AS 220.R2, Radwag, Poland) for determination of fresh weight. For determination of both dry weight and moisture content, explants grown under the same conditions were pooled to reach fresh weight $0.7-1.3 \mathrm{~g}$ and then analyzed by a moisture analyzer (MB27, Ohaus, NJ, USA). The leaves were photographed (PowerShot G16, Canon, Japan) for leaf area determination immediately after collection one by one from the explant and the entire leaf area of the single explant was measured by using ImageJ software [28]. 


\subsection{Determination of the Chlorophyll and Carotenoids Content}

The contents of chlorophyll $a$, chlorophyll $b$, and total carotenoids were determined in methanolic extracts analyzed at 666, 653, and $480 \mathrm{~nm}$, respectively. Contents were calculated according to the equation published in ref. [29].

\subsection{Determination of Reactive Oxygen Species and Malondialdehyde}

Homogenates in potassium phosphate buffer $(50 \mathrm{mM}, \mathrm{pH} 7.0)$ were used for determination of reactive oxygen species. The content of hydrogen peroxide was determined using the $\mathrm{TiCl}_{4}$ method (410 nm) with $\mathrm{H}_{2} \mathrm{O}_{2}$ as a standard. Superoxide radical was measured as a nitrite produced by the reaction in a mixture of homogenate, $10 \mathrm{mM}$ hydroxylamine, $17 \mathrm{mM}$ sulfanilamid, $7 \mathrm{mM}$ $\alpha$-naphtylamine, and diethyl ether (530 nm). Sodium nitrite was used for calibration [30].

The extent of membrane lipid peroxidation was expressed as the amount of MDA. Trichloroacetic acid (TCA) homogenates were mixed with TCA-thiobarbituric acid (TBA) solution and heated for $30 \mathrm{~min}$ at $90^{\circ} \mathrm{C}$. The samples were analyzed after rapid cooling at a wavelength of $532 \mathrm{~nm}$. The MDA contents were calculated using the extinction coefficient of MDA-TBA complex $\left(155 \mathrm{mM}^{-1} \mathrm{~cm}^{-1}\right)$ and expressed as $\mu \mathrm{mol} \mathrm{MDA} \mathrm{g}^{-1} \mathrm{FW}[30]$.

\subsection{Statistical Analysis}

Statistical differences among the treatments and cultivars were evaluated using analysis of variance (ANOVA) followed by Tukey test $(p<0.05)$ in Minitab v. 19 software (Minitab LLC, Coventry, UK). Number of replications (n) in tables/figures denotes individual samples measured for each parameter.

\section{Results}

\subsection{Plant Growth, Water Content, and Leaf Area}

The overall appearance of the in vitro explants in both fruit species was affected by the increasing concentration of PEG. Figure 1 shows in the most pronounced manifestations that leaf drooping, wilting, browning, and reduction in area were induced by water stress in both plant species. These symptoms occurred earlier in apples, whereas the cherries displayed better growth and more green leaves. The growth of in vitro plant explants was determined based on fresh weight (FW), dry weight (DW), water content, and leaf area. Our results are summarized in Figure 2 (detailed data are given in Supplementary Materials-TablesSupplementary Materials-Tables S1 and S2). 


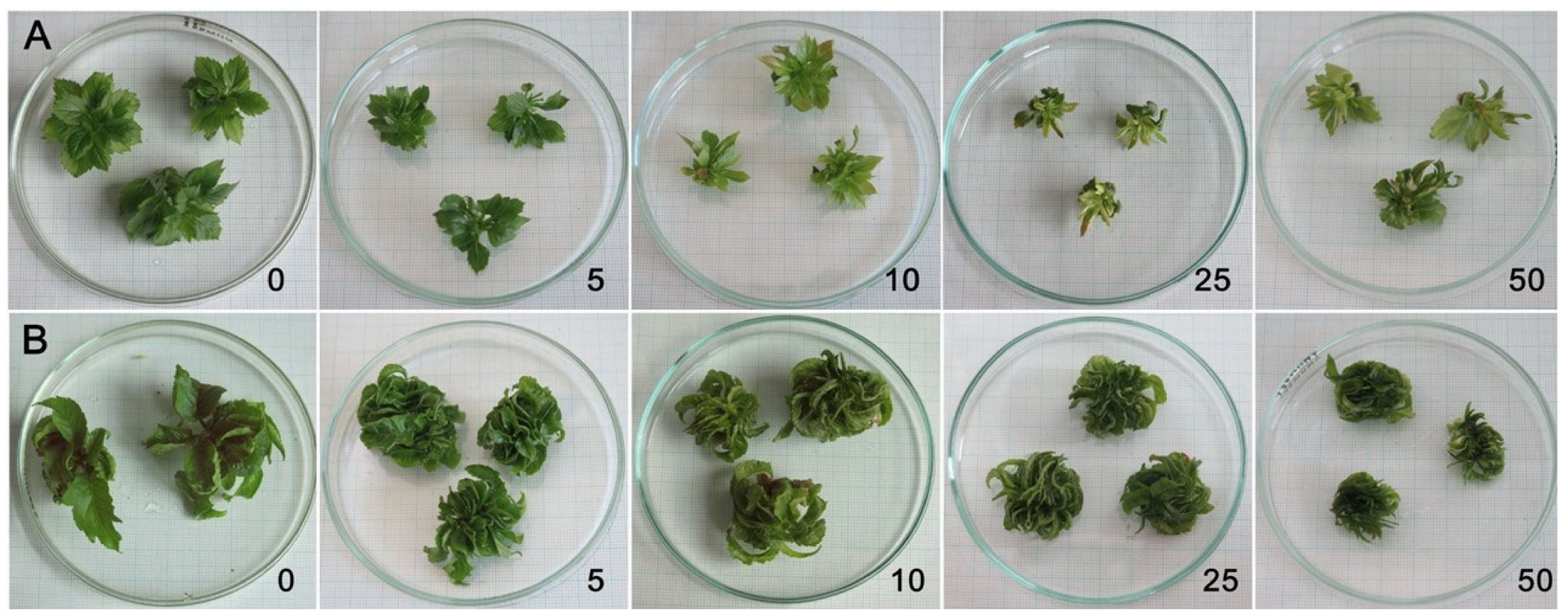

Figure 1. Effect of different concentration of polyethylene glycol (PEG-6000) on the growth and appearance of the in vitro culture of apple cultivar "Idared" (A) and cherry cultivar "Sunburst" (B); Numbers indicate PEG concentration in $\mathrm{g} \mathrm{L}^{-1}$ 

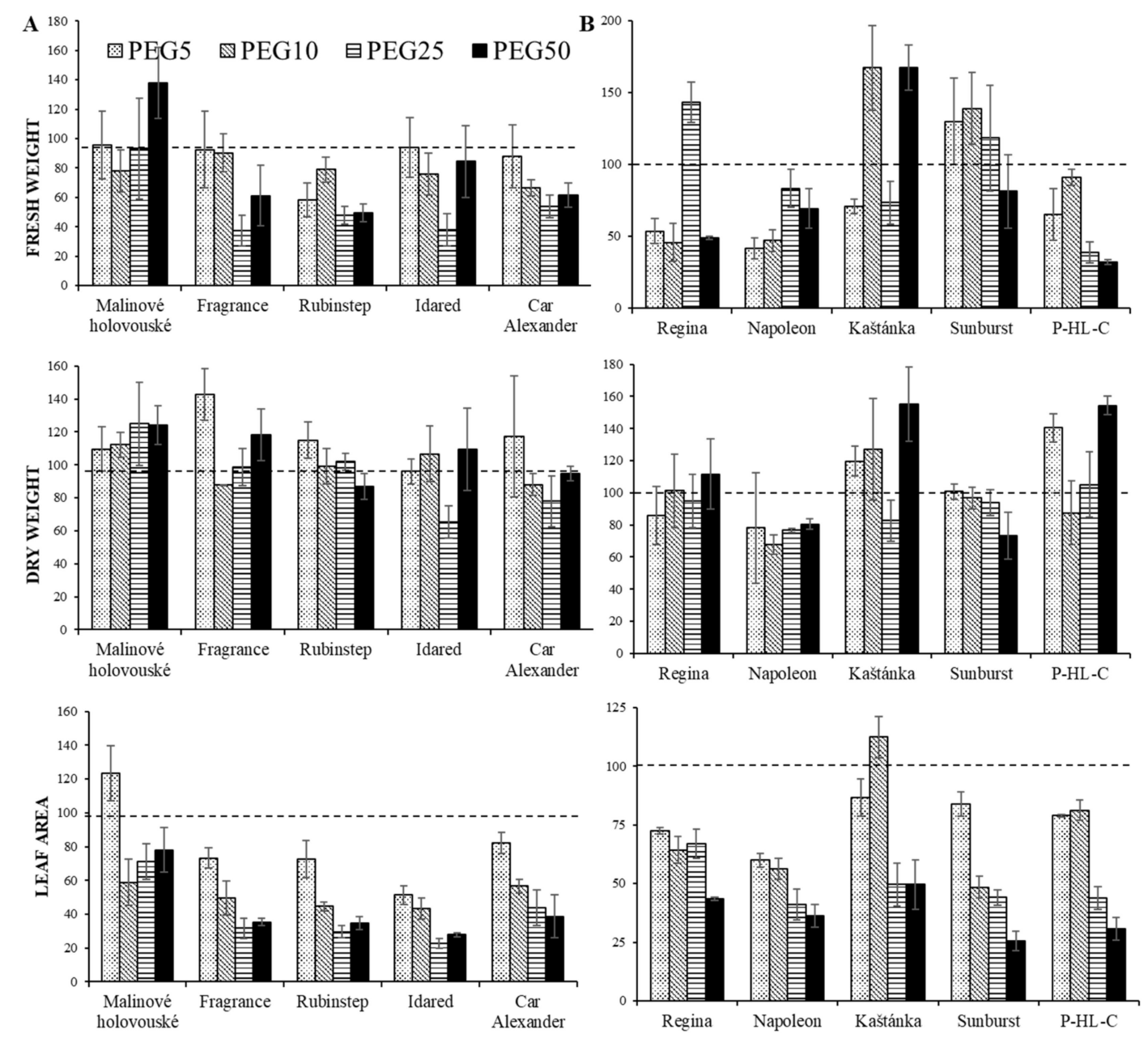

Figure 2. Effect of different concentration of PEG-6000 on content of fresh weight (g), dry weight $(\mathrm{g})$, and leaf area $\left(\mathrm{mm}^{2}\right)$ in in vitro culture of apple (A) and cherry (B) cultivars. All bar values were recalculated relative to the compound content in untreated samples taken as $100 \%$ (dashed line). Error bars represent means \pm SDs $(n=3)$.

A decrease in FW with increasing concentration of PEG in comparison with plants grown in medium containing no PEG (PEG0) was observed for apple cultivars most significantly for "Fragrance" in PEG25 and PEG50, for "Rubinstep" in PEG25 and PEG50, for "Idared" in PEG25, and for "Car Alexander" in PEG25. Within the cultivars themselves, the lowest FW in PEG0 plants was recorded for cultivar "Malinové holovouské" for which we also observed the lowest decrease. In contrast, the FW of PEG0 plants was the highest for the "Rubinstep" and "Car Alexander" cultivars and, at the same time, the decrease was more pronounced with the increasing concentration of PEG. A considerable variability in FW content was monitored for cherry plants, meaning it was not possible to unambiguously determine the interdependence between increasing PEG concentration and FW. A significant decrease in FW compared to PEG0 plants was observed in cultivars "Regina" (PEG 5, PEG 10, and PEG25), "Napoleonova" (PEG5 and PEG10), and "P-HL-C" (PEG 5, PEG25, and PEG50).

The decrease in FW was directly related to the decrease in the leaf area. Increasing PEG concentration led to a significant decrease in the leaf area of all tested cultivars, notably at PEG25 and PEG50. Figure 1 illustrated the most significant decrease (compared to control plants) observed for the apple cultivar "Idared" which was 4.2 times. The decrease (compared to control plants) in cherry cultivar "Sunburst" was 4 times. Overall, cherries exhibited larger leaf areas compared to apples, but the area decrease was more pronounced. The smallest leaf area was observed in "Malinové holovouské" and at the same 
time, the lowest decrease in leaf area was recorded here. The water content in the tissues was also significantly negatively affected with an increase in PEG concentration.

\subsection{Chlorophyll and Carotenoids Content}

Drought stress induced by PEG negatively influenced the content of chlorophylls in all cultivars of both tested species. Figure 3 and Table S3 show that increased concertation of PEG in apple cultivars resulted in simultaneous depression of chlorophyll $a$ and $b$. The lowest level of chlorophyll $a$ in PEG0 plants was observed in the cultivar "Fragrance", whereas the "Car Alexander" featured the highest 2 times higher concentration. The most significant decrease of $53 \%$ was observed in "Rubinstep". A similar trend was also observed for chlorophyll $b$. For the cherry cultivars, the concentrations of chlorophyll $a$ and $b$ were generally higher compared to apple cultivars (Table S4). At the same time, the differences in chlorophyll levels between individual cultivars were not significant. The highest value of chlorophyll $a$ in PEG0 plants was observed in "Kaštánka" while the 1.2 times lower one in the "P-HL-C" cultivar. An approximately 1.4 times decrease in the content due to increased PEG concentration was similar within all cultivars. The decrease in contents of chlorophyll $b$ was always the most pronounced in PEG5 plants, with the exception of the cultivar "Kaštánka", where it was observed at the concentration PEG10.
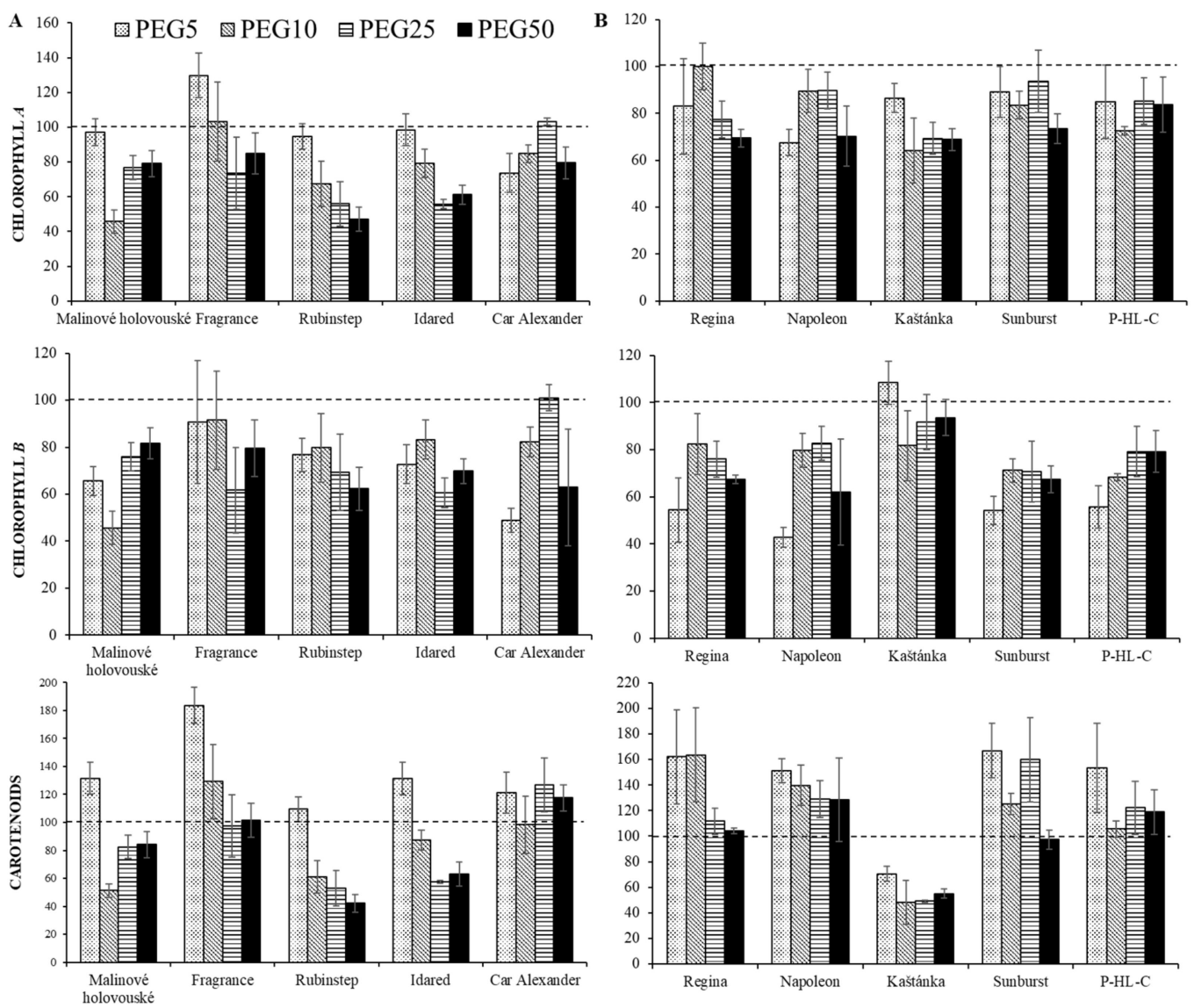

Figure 3. Effect of different concentration of PEG-6000 on content of chlorophyll $a\left(\mathrm{mg} \mathrm{g}^{-1} \mathrm{FW}\right)$, chlorophyll $b\left(\mathrm{mg} \mathrm{g}^{-1} \mathrm{FW}\right)$ and total carotenoids $\left(\mathrm{mg} \mathrm{g}^{-1} \mathrm{FW}\right)$ in in vitro culture of apple (A) and cherry (B) cultivars. All bar values were recalculated relative to the compound content in untreated samples taken as $100 \%$ (dashed line). Error bars represent means \pm SDs $(n=3)$. 
Simulated water deficit affected the content of total carotenoids differently as demonstrated in Figure 3 (Tables S3 and S4). Compared to PEG0, all apple cultivars displayed an increase in total carotenoids when the lowest concentration of PEG (PEG5) was used with most significant effect only in "Fragrance". A similar accumulation trend was also recorded for cherries. A significant increase was observed only in "Sunburst". In contrast, the highest values were reached in "Kaštánka" PEG0 plants. Higher PEG concentrations led in apples to a decrease in carotenoids content below the level of control plants (PEG0).

\subsection{Oxidative Status and Membrane Damage}

Figure 4 showed that PEG-induced osmotic stress slightly affected the overall oxidation status of the plants. $\mathrm{H}_{2} \mathrm{O}_{2}$ levels were generally higher in both PEG0 and stressed cherry plants compared to apples. The apple cultivars differed considerably from each other. Relatively low values measured for control and stressed plants were recorded for "Fragrance", "Car Alexander", and "Idared". However, a 2.7 times $\mathrm{H}_{2} \mathrm{O}_{2}$ increase due to PEG was pronounced. On the contrary, relatively high values with their increase comparable to cherries, were found in the cultivar "Malinové holovouské". Due to PEG treatment, a simultaneous increase in amounts of superoxide radicals was typical of all cultivars. The only exception was the cultivar "Napoleonova" which featured a decrease below the values monitored in PEG0 plants. Low levels of superoxide radical in PEG0 plants were recorded in apple cultivars "Fragrance" and "Idared", but at the same time, the most noticeable increase was recorded here, 2.5 times (PEG25) and 3.1 times (PEG50), respectively. Within cherries, the most significant increase in superoxide radical was recorded in the cultivar 'P-HL-C', amounting for 1.8 times compared to PEG0 plants.
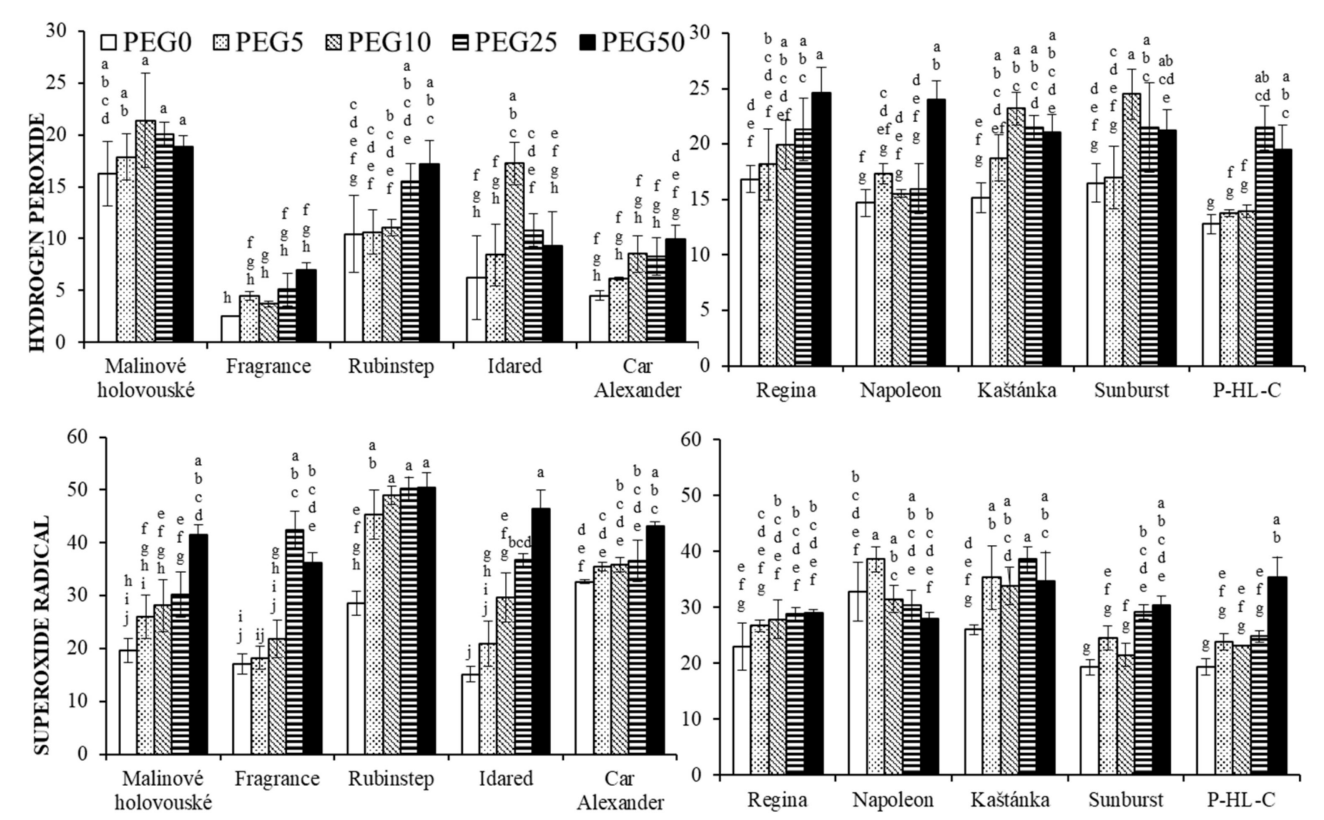

Figure 4. Effect of different concentration of PEG-6000 on content of hydrogen peroxide $\left(\mu \mathrm{mol} \mathrm{g}^{-1} \mathrm{FW}\right)$ and superoxide radicals $\left(\mu \mathrm{g} \mathrm{g}^{-1} \mathrm{FW}\right)$ in in vitro culture of apple and cherry cultivars. Error bars represent means \pm SDs $(n=3)$. Values within column, followed by the same letter $(\mathrm{s})$, are not significantly different according to Tukey's test $(p<0.05)$.

The accumulation of reactive oxygen species led to damage of membrane lipids expressed as a change in the content of MDA (Figure 5). The values in the PEG0 plants did not differ significantly within the apple cultivars. The highest increase of 1.7 times for PEG50 was observed in "Malinové holovouské". The MDA levels in cherries were generally lower for both non-treated and PEG treated cultivars. However, even the highest values observed in stressed plants did not reach the PEG0 values 
found for apple cultivars. The increase due to the increasing concentration of PEG was 2.3 and 2.7 times more pronounced for "Kaštánka" and "Napoleonova", respectively.

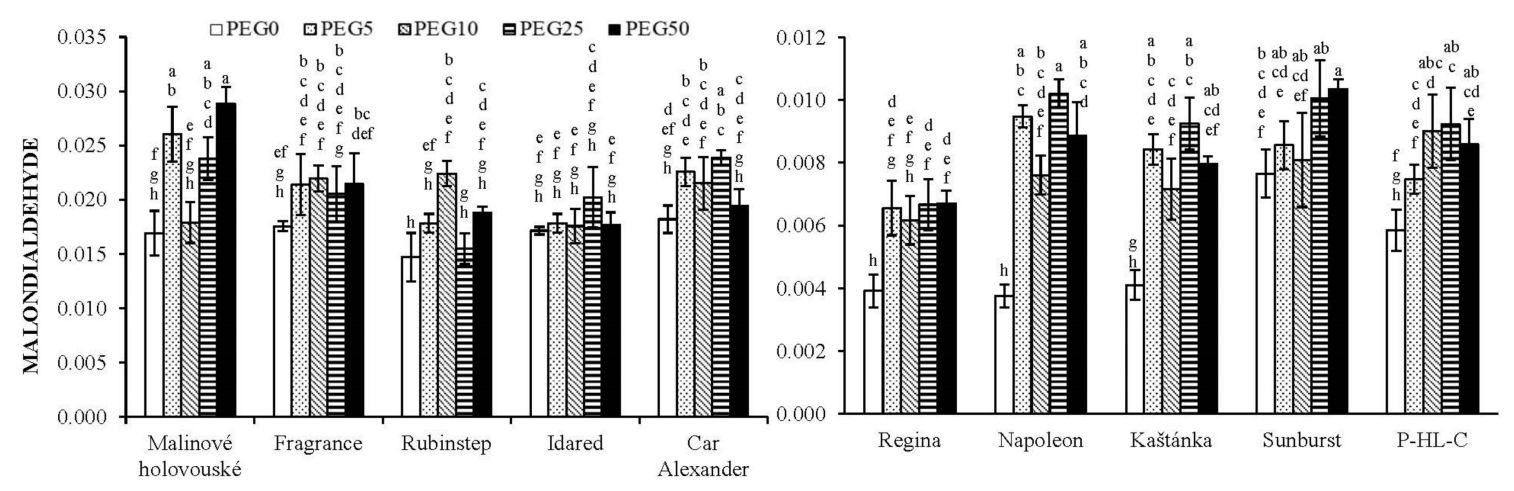

Figure 5. Effect of different PEG-6000 concentration on content of malondialdehyde ( $\left.\mu \mathrm{mol} \mathrm{g}{ }^{-1} \mathrm{FW}\right)$ in in vitro culture of apple and cherry cultivars. Error bars represent means \pm SDs $(n=3)$. Values within column, followed by the same letter(s), are not significantly different according to Tukey's test $(p<0.05)$.

\section{Discussion}

Apple and cherry are important fruit trees grown predominantly in temperate regions of the world. Limited water availability is a serious threat of production. Therefore, improvements in crop productivity under drought conditions are vital to keep global food security. The reactions of plants to the limited water regime are usually monitored at several levels, based on selected morphological, physiological, and biochemical parameters that have proven to be good indicators of drought sensitivity/tolerance. We tested, via induced osmotic stress, drought tolerance of five apple and five cherry cultivars by examining their physiological and biochemical parameters under progressive drought-like stress conditions.

Plant wilting, leaf twisting, and reduction in water content, are among the primary manifestations of drought stress. Shortage in water content and the associated decrease in nutrient availability lead to a reduction in cell division and cell proliferation resulted in overall reduction of leaf area [31]. A significant reduction in leaf area and total fresh and dry weight with increasing level of water stress was observed [32,33]. Moreover, several studies confirmed with sorghum [34], guava [35], grass pea [36], apples [37], and almonds [38] that drought tolerant genotypes displayed less damage than the susceptible counterparts. The results of our study demonstrate a negative relationship between water stress and growth parameters such as FW, DW, and leaf area although the response of tested cultivars differed in comparison to previously published studies. Cultivars "Malinové holovouské" and "Car Alexander" are thought to be varieties of low drought resistance [18]. We confirmed this only for "Car Alexander" in which we observed a significant decrease in FW and leaf area. However, these differences were minimal for "Malinové holovouské". "Napoleonova" is reported as a tolerant cherry to drought [22]. Here, we recorded a significant decrease in FW and leaf area but the water content remained constant.

Structural damages to chloroplasts due to ROS formation and/or photodegradation of the pigments probably led to loss of chlorophylls in dehydrated plants. The rootstock chloroplasts became deform in the water stressed apple, stacking of grana was less frequent, and thylakoids were loosened and distorted [37]. Decrease in photosynthetic pigments resulting in leaf yellowing or in an extreme case in leaf necrosis are common visual symptoms under severe water deficit. We noticed in our experiments a reduction in chlorophyll that was accompanied by yellowing and browning of the leaves at the highest concentrations of PEG as shown in Figure 1. Similar responses were also reported in cherry [39] and Prunus [40]. However, none of these studies focused in detail on individual types of chlorophylls. A detailed analysis of pigments is given in Šircelj et al. [41] who noticed a significant decrease in 
chlorophyll $a$ and $b$ after severe water deficit for apple cultivar "Jonagold Wilmuta". Similar to our study, mild stress led to a significant increase in carotenoids, specifically $\beta$-carotene [41] that is a major defense to generation of singlet oxygen in photosynthetic tissue through direct quenching of triplet chlorophyll. Severe stress reduced $\beta$-carotene level [6]. Of the other pigments, there was an increase in content of zeaxanthin, a member of the xanthophyll cycle which being a stimulant of non-photochemical quenching and lipid-protective antioxidant plays a direct photoprotective role [41]. Simultaneously with a decrease in chlorophyll, fluorescence of the chlorophyll also changed, namely the maximum photochemical efficiency and effective PSII quantum yield [12,42]. The drop in content of photosynthetic pigments accompanied with inhibition of chlorophyll fluorescence, electron transport rate, and photochemical quenching is a reliable indicator of limited capacity of the photosynthetic system [43]. A decrease in the photosynthetic rate, transpiration rate, and stomatal conductance has been observed in several species [40-42].

One of the many manifestations of negative environmental stimuli is the formation of ROS, including hydrogen peroxide, superoxide, and hydroxyl radicals. Their overproduction can lead to protein degradation, lipid peroxidation, and enzyme inhibition [44]. Besides their toxic properties, they often appear as signaling molecules in mediating adequate defense responses [45]. We found that water limitation caused significant growth in $\mathrm{H}_{2} \mathrm{O}_{2}$ and superoxide radical concentrations in all cultivars of both species. Enhanced production of ROS was also detected by others in apple leaves [12,37] or cherry rootstock [39].

The degree of oxidative damage can usually be expressed as a change in MDA content, a product of ROS-mediated oxidation of polyunsaturated membrane lipids. Oxidative damage to membranes disrupts the complexity of cellular structures [37]. Electron flux occurs [2], which in turn disrupts the homeostasis of the internal environment and the complexity of individual metabolic pathways. Here, a gradual increment of MDA content as the effects of water shortage indicates that this parameter was directly related to drought similar to previous reports $[39,46]$. It is well known that different plants and even cultivars of a single plant respond to stress differently. This can result in a different accumulation of monitored ROS and MDA as in the present study. Zhong et al. [46] studied five kiwifruit species that differed significantly in MDA accumulation. Drought-sensitive Malus hupehensis apples had a higher $\mathrm{H}_{2} \mathrm{O}_{2}$ rate and superoxide radical generation and subsequent lipid peroxidation in comparison with drought-tolerant M. prunifolia [37]. In our case, the increase in $\mathrm{H}_{2} \mathrm{O}_{2}$ and MDA content was more pronounced for cherries. This means that cherries reacted more sensitively compared to apples. On the other hand, the increment in the superoxide radical was more pronounced in apple cultivars. These differences can be related to the different activity of antioxidant enzymes and other antioxidants. For a better understanding, it is necessary to determine the activity of enzymes such as catalase, ascorbate peroxidase, superoxide dismutase, as well as levels of other antioxidants such as ascorbic acid, phenolic substances, and total plant antioxidant activity.

In vitro tissue culture represents a biotechnological technique that has been used to genetically improve cultivars and rootstocks. Another option enabling an increase in the stress resistance in many plant species is the so-called polyploidization. For example, Zhang et al. [47] showed that autotetraploid apple cultivar "Hanfu" and "Gala" had, under drought stress, higher relative water content and chlorophyll fluorescence parameters, and lower MDA and proline levels compared to diploid apple.

\section{Conclusions}

Our work proposes the use of in vitro cultivation of fruit plants with subsequent evaluation of selected physiological parameters as a useful tool in the search for drought resistant or tolerant fruit cultivars. In this study, we examined the reaction of in vitro apple and cherry culture to drought-like stress simulated by enhancing polyethylene glycol concentration in the growing medium. The water content, leaf areas, and chlorophyll content in both fruit species was negatively affected by water deficit conditions. Interestingly, under drought stress, cherries and apples showed different changes in 
ROS production that could be related to different antioxidant strategies. Based on the data from our study, we can only roughly estimate the tolerance order of individual cultivars as follows: for apple "Malinové holovouské" > "Fragrance" > "Car Alexander" $\geq$ "Rubinstep" > "Idared"; and for cherry "Napoleonova" > "Regina" > "Kaštánka" $\geq$ "P-HL-C" $\geq$ "Sunburst". However, it should be noted the conclusion is very preliminary and future research focused on determination of the antioxidant enzyme activity and levels of antioxidants will be helpful for better understanding of the mechanism of drought stress in the apple and cherry trees. As well as future research focused on implementation of the acquired knowledge in vitro to ex vitro environment would be beneficial.

Supplementary Materials: The following are available online at http://www.mdpi.com/2073-4395/10/11/1689/s1, Table S1: Effect of different concentration of PEG-6000 on fresh weight, dry weight, water content, and leaf area of in vitro culture of apple cultivars. Data are means $\pm \operatorname{SD}(n=3)$. Values within column, followed by the same letter(s), are not significantly different according to Tukey's test $(p<0.05)$., Table S2: Effect of different concentration of PEG-6000 on fresh weight, dry weight, water content, and leaf area of in vitro culture of cherry cultivars. Data are means \pm SD $(n=3)$. Results of statistic are the same as in Table S1, Table S3: Effect of PEG-6000 concentration on chlorophylls and total carotenoids contents in in vitro culture of apple cultivars. Data are means \pm SDs $(n=3)$. Results of statistic are the same as in Table S1, Table S4: Effect of PEG-6000 concentration of on chlorophylls and total carotenoids contents in in vitro culture of cherry cultivars. Data are means \pm SDs $(n=3)$. Results of statistic are the same as in Table S1.

Author Contributions: Conceptualization, Z.K. and P.J.; methodology, Z.K. and P.J.; investigation, Z.K., P.J., J.T. and D.D.; resources, P.J. and L.D.; data curation, Z.K. and P.J.; writing-original draft preparation, Z.K., P.J. and L.D.; writing-review and editing, Z.K. and P.J.; supervision Z.K. and P.J.; All authors have read and agreed to the published version of the manuscript.

Funding: This research was funded by Technology Agency of the Czech Republic (programme ZETA 2), grant number TJ02000066 (Research of laboratory method for prediction of tolerance of fruit crops to drought).

Acknowledgments: The authors would like to thank Jiřina Rachotová for her technical assistance on this research.

Conflicts of Interest: The authors declare no conflict of interest and the funders had no role in the design of the study; in the collection, analyses, or interpretation of data; in the writing of the manuscript, or in the decision to publish the results.

\section{References}

1. Alizadeh, V.; Shokri, V.; Soltani, A.; Yousefi, M.A. Effects of Climate Change and Drought-Stress on Plant Physiology. Int. J. Adv. Biol. Biom. Res 2015, 3, 38-42.

2. Bolat, I.; Dikilitas, M.; Ikinci, A.; Ercisli, S.; Tonkaz, T. Morphological, physiological, biochemical characteristics and bud success responses of myrobolan 29 c plum rootstock subjected to water stress. Can. J. Plant Sci. 2016, 96, 485-493. [CrossRef]

3. Tuna, A.L.; Kaya, C.; Ashraf, M. Potassium sulfate improves water deficit tolerance in melon plants grown under glasshouse conditions. J. Plant Nutr. 2010, 33, 1276-1286. [CrossRef]

4. Jaleel, C.A.; Manivannan, P.; Wahid, A.; Farooq, M.; Al-Juburi, H.J.; Somasundaram, R.; Panneerselvam, R. Drought stress in plants: A review on morphological characteristics and pigments composition. Int. J. Agric. Biol. 2009, 11, 100-105.

5. Anjum, S.A.; Ashraf, U.; Zohaib, A.; Tanveer, M.; Naeem, M.; Ali, I.; Tabassum, T.; Nazir, U. Growth and developmental responses of crop plants under drought stress: A review. Zemdirb. Agric. 2017, 104, $267-276$. [CrossRef]

6. Farooq, M.; Wahid, A.; Kobayashi, N.; Fujita, D.; Basra, S.M.A. Plant drought stress: Effects, mechanisms and management. Agron. Sustain. Dev. 2009, 29, 185-212. [CrossRef]

7. Mibei, E.K.; Ambuko, J.; Giovannoni, J.J.; Onyango, A.N.; Owino, W.O. Carotenoid profiling of the leaves of selected African eggplant accessions subjected to drought stress. Food Sci. Nutr. 2016, 5, 113-122. [CrossRef]

8. Khayatnezhad, M.; Gholamin, R. The effect of drought stress on leaf chlorophyll content and stress resistance in maize cultivars (Zea mays). Afr. J. Microbiol. Res. 2012, 6, 2844-2848. [CrossRef]

9. Li, R.; Guo, P.; Michael, B.; Stefania, G.; Salvatore, C. Evaluation of Chlorophyll Content and Fluorescence Parameters as Indicators of Drought Tolerance in Barley. Agric. Sci. China 2006, 5, 751-757. [CrossRef] 
10. Meher; Shivakrishna, P.; Ashok Reddy, K.; Manohar Rao, D. Effect of PEG-6000 imposed drought stress on RNA content, relative water content (RWC), and chlorophyll content in peanut leaves and roots. Saudi J. Biol. Sci. 2018, 25, 285-289. [CrossRef]

11. Young, A.; Lowe, G. Carotenoids-Antioxidant Properties. Antioxidants 2018, 7, 28. [CrossRef] [PubMed]

12. Wang, Z.; Li, G.; Sun, H.; Ma, L.; Guo, Y.; Zhao, Z.; Gao, H.; Mei, L. Effects of drought stress on photosynthesis and photosynthetic electron transport chain in young apple tree leaves. Biol. Open 2018, 7, bio035279. [CrossRef] [PubMed]

13. Farooq, M.; Wahid, A.; Lee, D.-J.; Cheema, S.A.; Aziz, T. DROUGHT STRESS: Comparative Time Course Action of the Foliar Applied Glycinebetaine, Salicylic Acid, Nitrous Oxide, Brassinosteroids and Spermine in Improving Drought Resistance of Rice: Improving rice drought tolerance. J. Agron. Crop Sci. 2010, 196, 336-345. [CrossRef]

14. Bhadra, S.; Roy, B.; Ghimiray, T.S. Polyethyleneglycol mediated rapid in vitro screening of rice (Oryza sativa L.) genotypes for drought tolerance. Ind. Jrnl. Gen. Plnt. Bree. 2017, 78, 142. [CrossRef]

15. Sakthivelu, G.; Akitha Devi, M.K.; Giridhar, P.; Rajasekaran, T.; Nedev, T.; Kosturkova, G. Drought-induced alterations in growth, osmotic and in vitro regeneration of soybean cultivars. Genet. Appl. Plant Physiol. 2008, 34, 103-112.

16. Osmolovskaya, N.; Shumilina, J.; Kim, A.; Didio, A.; Grishina, T.; Bilova, T.; Keltsieva, O.A.; Zhukov, V.; Tikhonovich, I.; Tarakhovskaya, E.; et al. Methodology of Drought Stress Research: Experimental Setup and Physiological Characterization. IJMS 2018, 19, 4089. [CrossRef]

17. Kautz, B.; Noga, G.; Hunsche, M. PEG and drought cause distinct changes in biochemical, physiological and morphological parameters of apple seedlings. Acta Physiol. Plant. 2015, 37, 162. [CrossRef]

18. ̌níha, J. České Ovoce-díl III. Jablka; České nakladatelství: Praha, Czech Republic, 1919.

19. Boček, S. Ovocné Dřeviny v Krajině: Pilotní vZdělávací Program, Hostětín 2007/8: Sbornîk Přednášek a Seminárních Prací; ZO ČSOP Veronica: Brno, Czech Republic, 2008; ISBN 978-80-904109-2-3.

20. Richter, M. Malý Obrazový Atlas Odrůd Ovoce. 3; TG tisk: Lanškroun, Czech Republic, 2004; ISBN 978-80-903487-2-1.

21. Nove Odrudy Ovoce = New Cultivars of Fruit; Vyzkumny a slechtitelsky ustav ovocnarsky Holovousy: Holovousy, Czech Republic, 2007; ISBN 978-80-87030-04-2.

22. Kutina, J. Pomologický Atlas 1; Brázda: Praha, Czech Republic, 1991; ISBN 80-209-0089-6.

23. Blažek, J. Odrůda jabloně Rubinstep. Vědecké Práce Ovocnářské 2001, 17, 163-165.

24. Kutina, J.; Holeček, S. Pomologický Atlas 2; Brázda: Praha, Czech Republic, 1992; ISBN 978-80-209-0192-7.

25. Lane, W.D.; Schmid, H. Lapins and Sunburst sweet cherry. Can. J. Plant Sci. 1984, 64, 211-214. [CrossRef]

26. Blažková, J. Pěstování Třešní na Slabě Rostoucích Podnožích; Výzkumný a šlechtitelský Ústav Ovocnářský Holovousy: Holovousy, Czech Republic, 2005; ISBN 978-80-902636-8-0.

27. Murashige, T.; Skoog, F. A Revised Medium for Rapid Growth and Bio Assays with Tobacco Tissue Cultures. Physiol. Plant. 1962, 15, 473-497. [CrossRef]

28. ImageJ Home Page. Available online: http://rsbweb.nih.gov/ij (accessed on 30 October 2020).

29. Wellburn, A.R. The spectral determination of chlorophyll $a$ and $b$, as well as total Carotenoids, using various solvents with spectrophotometers of different resolutions. J. Plant. Physiol. 1994, 144, 307-313. [CrossRef]

30. Ducaiova, Z.; Sajko, M.; Mihalicova, S.; Repcak, M. Dynamics of accumulation of coumarin-related compounds in leaves of MatriCaria chamomilla after methyl jasmonate elicitation. Plant Growth Regul. 2016, 79, 81-94. [CrossRef]

31. Tardieu, F. Plant response to environmental conditions: Assessing potential production, water demand, and negative effects of water deficit. Front. Plant Physiol. 2013, 4, 1-11. [CrossRef]

32. Karimi, S.; Hojati, S.; Eshghi, S.; Moghaddam, R.N.; Jandoust, S. Magnetic exposure improves tolerance of fig 'Sabz' explants to drought stress induced in vitro. Sci. Hortic. 2012, 137, 95-97. [CrossRef]

33. Turhan, H.; Baser, I. In vitro and in vivo water stress in sunflower. Helia 2004, 27, 227-236. [CrossRef]

34. Tsago, Y.; Andargie, M.; Takele, A. In vitro selection of sorghum (Sorghum bicolor (L) Moench) for polyethylene glycol (PEG) induced drought stress. Plant Sci. Today 2014, 1, 62-68. [CrossRef]

35. Abouzaid, E.; El-Sayed, E.S.N.; Mohamed, E.S.A.; Youseff, M. Molecular Analysis of Drought Tolerance in Guava Based on In Vitro PEG Evaluation. Trop. Plant Biol. 2016, 9, 73-81. [CrossRef]

36. Piwowarczyk, B.; Kamińska, I.; Rybiński, W. Influence of PEG Generated Osmotic Stress on Shoot Regeneration and Some Biochemical Parameters in Lathyrus Culture. Czech J. Genet. Plant Breed. 2014, 50, 77-83. [CrossRef] 
37. Wang, W.; Liang, D.; Li, C.; Hao, Y.; Ma, F.; Shu, F. Influence of drought stress on the cellular ultrastructure and antioxidant system in leaves of drought-tolerant and drought-sensitive apple rootstocks. Plant Physiol. Bioch. 2012, 51, 81-89. [CrossRef]

38. Gikloo, S.T.; Elhami, B. Physiological and morphological responsesof two almond cultivars to drought stress and cycocel. Int. Res. J. Appl. Bas. Sci. 2012, 3, 1000-1004.

39. Sivritepe, N.; Erturk, U.; Yerlikaya, C.; Turkan, I.; Bor, M.; Ozdemir, F. Response of the cherry rootstock to water stress induced in vitro. Biol. Plant. 2008, 52, 573-576. [CrossRef]

40. Jiménez, S.; Dridi, J.; Gutiérrez, D.; Moret, D.; Irigoyen, J.J.; Moreno, M.A.; Gogorcena, Y. Physiological, biochemical and molecular responses in four Prunus rootstocks submitted to drought stress. Tree Physiol. 2013, 33, 1061-1075. [CrossRef]

41. Šircelj,H.; Tausz, M.; Grill, D.; Batič, F. Detecting different levels of drought stress in apple trees (Malus domestica Borkh.) with selected biochemical and physiological parameters. Sci. Hortic. 2007, 113, 362-369. [CrossRef]

42. Liu, B.; Liang, J.; Tang, G.; Wang, X.; Liu, F.; Zhao, D. Drought stress affects on growth, water use efficiency, gas exchange and chlorophyll fluorescnce of Juglans rootstocks. Sci. Hortic. 2019, 250, 230-235. [CrossRef]

43. Baker, N.R.; Rosenqvist, E. Applications of chlorophyll fluorescence can improve crop production strategies: An examination of future possibilities. J. Exp. Bot. 2004, 55, 1607-1621. [CrossRef]

44. Appel, K.; Hirt, H. Reactive oxygen species: Metabolism, oxidative stress, and signal transduction. Annu. Rev. Plant Biol. 2004, 55, 373-399. [CrossRef] [PubMed]

45. Pérez-Pérez, M.E.; Lemaire, S.D.; Crespo, J.L. Reactive oxygen species and autophagy in plants and algae. Plant Physiol. 2012, 160, 156-164. [CrossRef] [PubMed]

46. Zhong, Y.-P.; Li, Z.; Bai, D.-F.; Qi, X.-J.; Chen, J.-Y.; Wei, C.-G.; Lin, M.-M.; Fang, J.-B. In Vitro Variation of Drought Tolerance in Five Actinidia Species. J. Am. Soc. Hortic. Sci. 2018, 143, 226-234. [CrossRef]

47. Zhang, F.; Xue, H.; Lu, X.; Zhang, B.; Wang, F.; Ma, Y.; Zhang, Z. Autotetraploidization enhances drought stress tolerance in two apple cultivars. Trees 2015, 29, 1773-1780. [CrossRef]

Publisher's Note: MDPI stays neutral with regard to jurisdictional claims in published maps and institutional affiliations.

(C) 2020 by the authors. Licensee MDPI, Basel, Switzerland. This article is an open access article distributed under the terms and conditions of the Creative Commons Attribution (CC BY) license (http://creativecommons.org/licenses/by/4.0/). 